\title{
リアルタイムキネマティックの傾斜計への応用
}

\author{
浪江 宏宗*・安田 明生**・岡村 知則***
}

\section{Application of Real-Time Kinematic GPS to Clinometer}

\author{
Hiromune NAMIE, Akio YASUDA and Tomonori OKAMURA
}

\begin{abstract}
Real-Time Kinematic (RTK) GPS has an ability to fix a position as the $\mathrm{cm}$ order by measuring the range from the GPS satellites with the accuracy of the 1/100 order of a carrier wavelength. The authors tried to evaluate the accuracy of the angle measurement of inclination by inferring the accuracy of altitude determination by RTK-GPS. A GPS antenna of user station is mounted on the edge of an oscillating table with $45 \mathrm{~cm}$ in arm length and about $10 \mathrm{~s}$ in oscillating period. The temporal variation of altitude agrees very well with the output of the capacitive type clinometer mounted on an oscillating center except the high frequency vibration of about $2 \mathrm{~cm}$ standard deviation which is measured at the stable condition. The output delay of the fix position is also measured to be 135.90 ms which can be neglected in the measurement of the ship's attitude. The application of the filtering may improve the accuracy in the angle measurement.
\end{abstract}

\section{1.はじめに}

リアルタイムキネマティック（Real-Time Kinematic GPS；以下RTK）は衛星測位システムの1つで、 センチメートルオーダの高精度測位が可能である。また、単独測位等と同様に、最低 4 機のGPS衛星さえ 連続的に追尾できれば、時間、場所等に制限されることなく、世界中で24時間の実時間利用が可能である。 RTKでは、4 機以上のGPS衛星から送信される搬送波を、それぞれ基準局、利用者局受信機で同時に追 尾し、その位相積算值データを測定することによって、利用者局受信機と各々2衛星との距離差を求める。 このとき、距離差計測の基準として用いられる搬送波の波長は、L1帯（約1.6GHz）で約 $19 \mathrm{~cm} 、 \mathrm{~L} 2$ 帯（約 $1.2 \mathrm{GHz})$ で約 $25 \mathrm{~cm}$ である。その波長の $1 / 100 に$ 近い位相分解能を得ることができ、センチメートルオーダ の高精度測位が可能となる ${ }^{(1)(2)(3)(4)(5) 。 ~}$

利用例としては、建設現場での建築資材等の位置決定、航空機の離着陸時における支援、船舶の自動離 着棧時における支援等が注目され始めている。また、RTKを用いた傾斜計も開発されている。

ここで、既にASHTECH社より市販されている、L1帯、L2帯2周波を観測可能な、24チャンネル装備の RTK傾斜計3DF ADUでは、動摇の測定精度は受信アンテナの間隔が1mの場合、標準偏差で $0.1^{\circ}$ 。また、 位相に関しても顕著な差は認められないと聞いている。しかし、測定值には、明らかに2 前後の誤差が生じ たり、かなりの位相遅延が観測される場合もあるようである(6)。さらに、搬送波位相積算値データや、角度 出力值に対して、何らかのフィルタ処理を行っているようで、この処理によって発生する遅延、そして実 時間性については明らかにされていない。

本研究では、これらの不明膫なスペックを明確化し、RTKの実時間で高精度な測位データが取得できる という利点を利用し、さらに高精度な傾斜計としての、利用可能性を検討する基礎的な評価実験を行った。

* 学生会員 東京商船大学大学院（干135 東京都江東区越中島 2-1-6)

** 正 会 員 東京商船大学（广135 東京都江東区越中島 $2-1-6$ )

***非 会 員 東京商船大学学部（T135 東京都江東区越中島 2-1-6) 


\section{2. 実験の概要}

図1に実験の概念図を示す。まず、あらかじめ測量 を行い、正確に位置の分かっている地点に、基準局 受信機のアンテナを設置した。次に、その地点から 約 $14 \mathrm{~m}$ 離れた位置にある、一軸動摇台の一端に、利用 者局受信機のアンテナを設置した。動摇台の支点か らアンテナまでの距離は $45 \mathrm{~cm}$ であった。また、支点 上に較正に用いた傾斜計を設置した。そして、支点 を中心に動摇台をシーソー運動させ、その振動をRTK と傾斜計で同時に測定した。なお、動摇台の振動周 期は、約 5 秒から 1 分間の間で適宜变え、数回実験 を行った。

実験に使用した受信機は、NovAtel社製3151R型2 台で、表 1 にその仕様を示す。基準局受信機と利用 者局受信機は、RS-232Cケーブルで直結しており、 基準局受信機で測定された搬送波位相積算值データ は、直接利用者局受信機に伝送している。また、較 正に用いた傾斜計は、Lucas社製P/N02755-01で、傾 斜による液面の変化を 4 枚のキャパシタプレートで 静電容量の変化に変換し、ピッチとロールの 2 軸を それぞれ同時に出力できるものである。検証の結果、 傾斜計の測角誤差は土0.5以下であった。しかし、応 答周波数に限界があり、動摇台の振動周波数が $0.5 \mathrm{~Hz}$ 以上になると、応答遅延が発生する。データのサン プリング周波数は、RTKが $5 \mathrm{~Hz}$ 、傾斜計は約 $15 \mathrm{kHz}$ であった。

受信機の測位精度を調べるために、実験に先だっ て取得したRTK定点測位データの中、测高度の時間 変化例を図 2 に示す。同図より、定点測位であるに もかかわらず、高度は一定の値を示さず、ランダム に変動しており、標準偏差 $\sigma$ は $2 \mathrm{~cm}$ 程度であることが 分かる。

次に、図 3 に、受信機から直接取得した、搬送波 位相積算値データを用いて計算した二重位相差の時 間变化例を示し、さらに、図4に、この二重位相差の 回帰曲線に対する分散を示す。その標準偏差は1波長 の約 0.045 倍で、距離に換算すると約 $8.8 \mathrm{~mm}$ となる。 よって、この値が、今回使用した受信機の測距精度 であるといえる。DOPの值と併せて、これら3つのパ ラメータにより、ほぼこの受信機の測位精度が評価 できる。

本実験では、GPS受信機から出力されている1PPS 信号を用いて、RTKと傾斜計の出力に対して、誤差 $1 \mathrm{~ms}$ 以内の同期を取っている。1PPS信号は、受信機

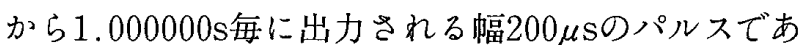
り、GPS時間と完全に同期している。そして、毎秒

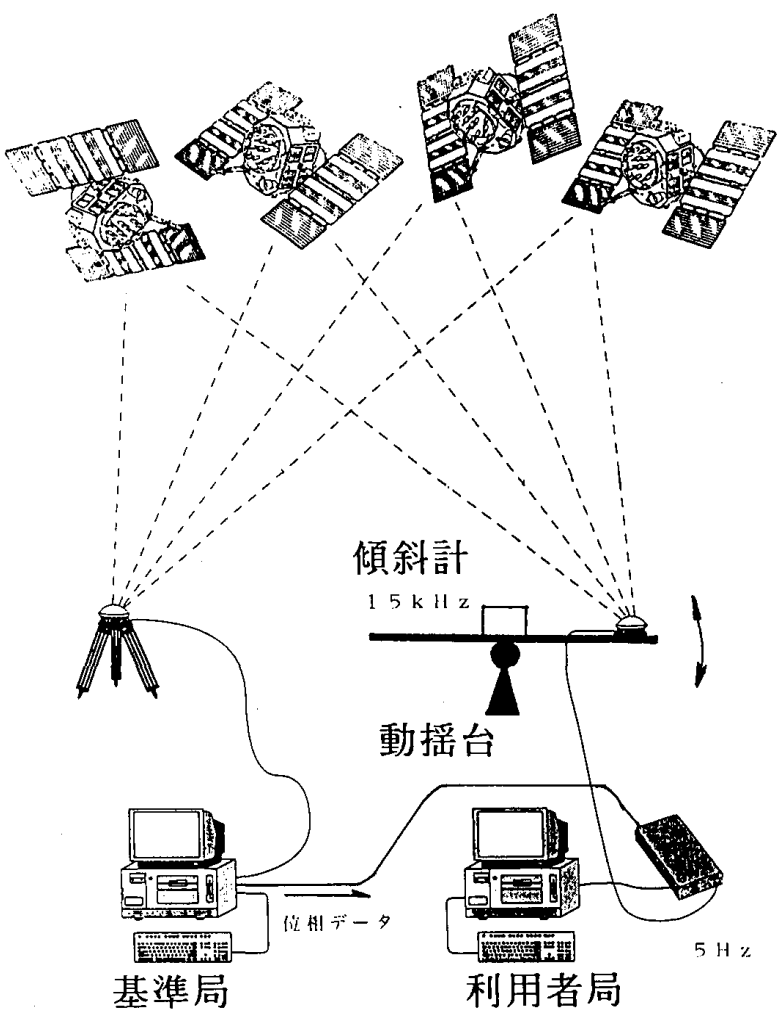

図 1 実験の概念図

表 1 GPS受信機の仕様

NovAtel Communications 社製の3151R型 $G P S$ 単独, DGPS, RTK-GPS 測位可能 受信周波数 $\mathrm{L} 1$ 帯 $(1.6 \mathrm{GHz})$ 受信コードＣ/Aコード 受信チャンネル 12 (最大 12 衛星) 最短測位周期 $\quad 0.20 \mathrm{~s}$ 外部入出力 2つのRS-232Cポート 測位利用衛星全可視衛星

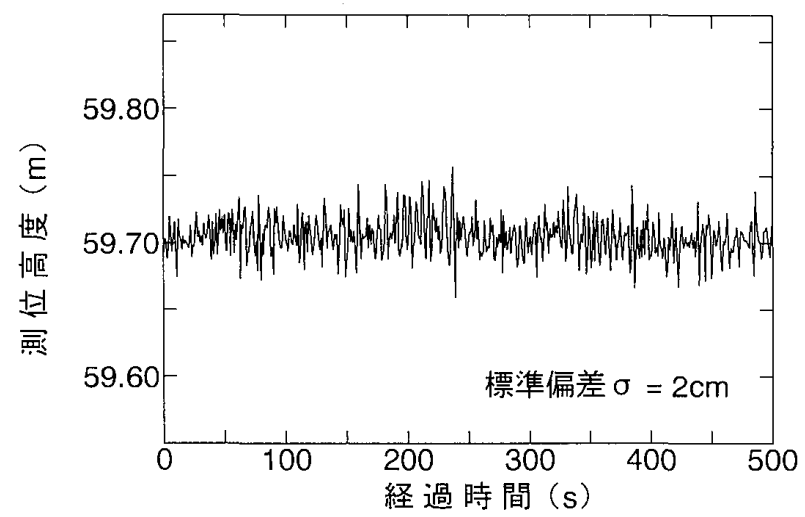

図 2 RTK定点測高度の時間変化例 


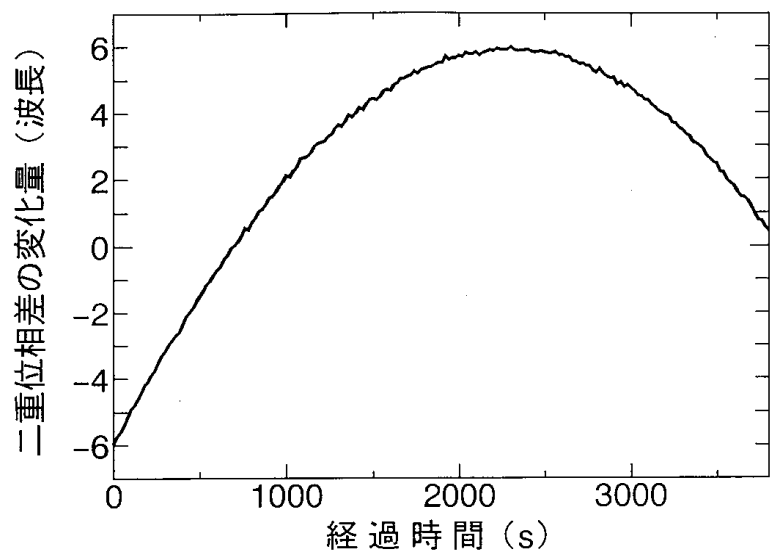

図 3 二重位相差の時間変化例

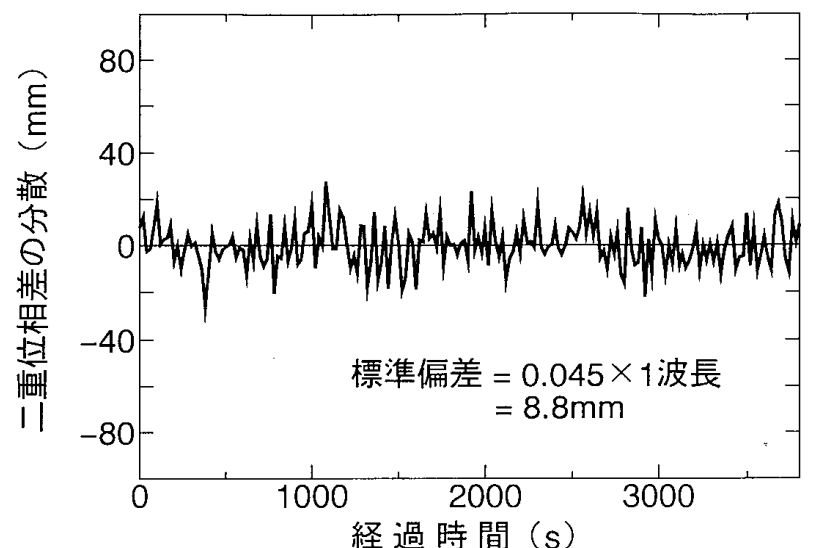

図 4 二重位相差の回帰曲線に対する分散

の正秒に出力されている。この信号を、傾斜計の $\mathrm{A} / \mathrm{D}$ 变換出力值の間に挿入、マークすることによ って、傾斜計の出力值と同期を取っている。一方、 RTK測位データには、測位時刻を示すGPS時間が 含まれており、その含まれている正秒の時刻と、 1PPS信号の出力時刻を一致させて同期を取ってい る。

図 5 に、実験時における衛星の幾何学的配置図 を、地平面図で示す。実験中は、常時6機か58機 の衛星がRTK測位に利用されており、VDOPの值 は、1.80から2.01の間で変化していた。

\section{3 . 実験結果}

図 6 に、RTKの测高度から求めた計算角度と、 比較に用いた傾斜計の出力角度の時間变化例を示 す。な拉、図中の直線は、角度が $00^{\circ}$ の位置を示す。 RTKによる計算角度は、傾斜計の出力角度に対し て、小振幅の振動をしていることが分かる。次に、 これらの值を、高度変化に変換したものを図 7 に 示す。RTKでは、傾斜計と比較して、振幅 $2 \mathrm{~cm}$ 程度 の小刻みな振動が見られ、先の計算角度にも、そ れが現れていることが分かる。これは、RTKの定 点測位データ中の測高度が、標準偏差 $\sigma 2 \mathrm{~cm}$ 程度で ランダムに変動していたことからも、当然の結果 であるといえる。動摇台の振動周期を变えても、 ほとんど同様の結果が得られた。

ここで、RTKの測高度から求めた計算角度誤差 Eaは、

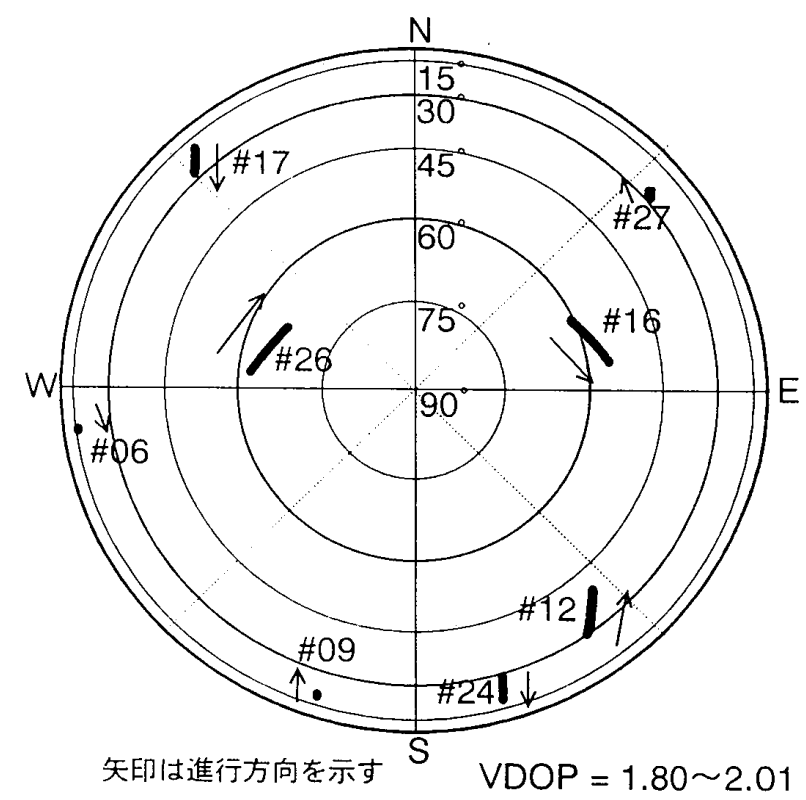

図 5 GPS衛星の幾何学的配置図 (地平面図)

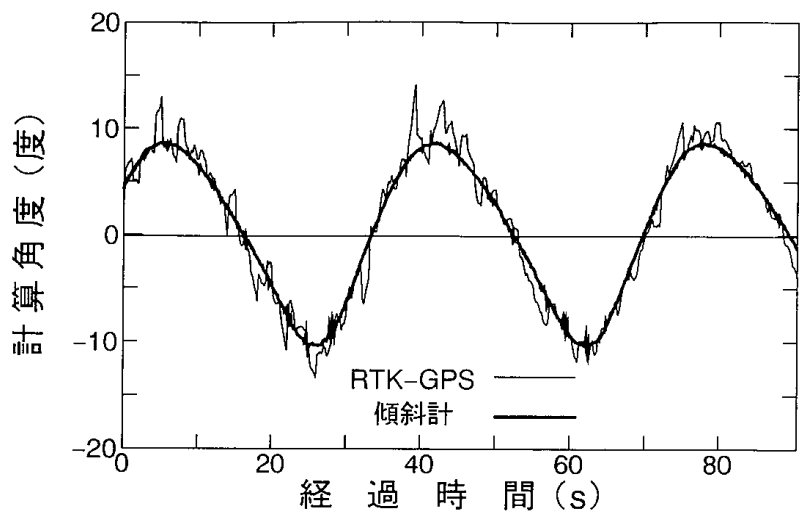

図 $6 R T K$ と傾斜計の計算角度の時間变化例

$$
E a=\tan ^{-1}(\sigma / l)
$$

で表される。ただし、のはRTKの測高度の標準偏差 $2 \mathrm{~cm}$ あ゙あ、はは動摇台の支点一アンテナ間距離である。

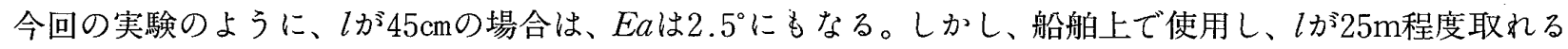
とすると、Eaが $0.1^{\circ}$ 以下の高精度な傾斜計を構成できることになる。 


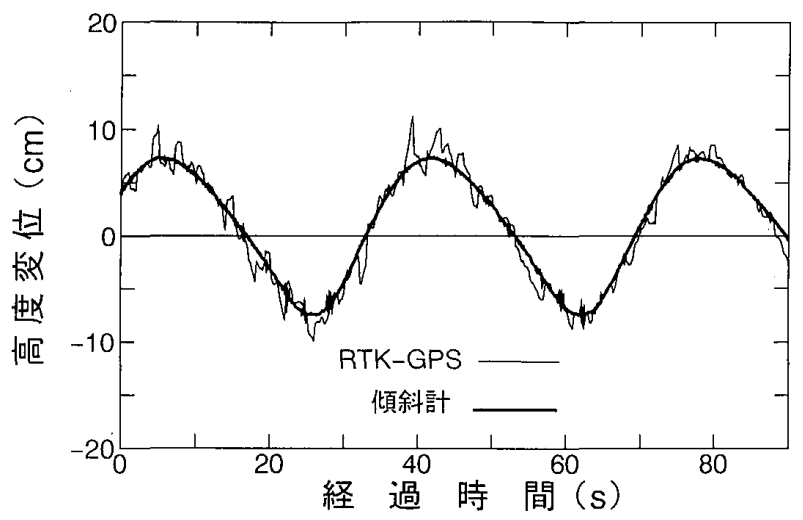

四 $7 \mathrm{RTK} \varepsilon$ 傾斜計の高度変位の時間変化例

\section{4. 実時間性評価}

次に、RTKの実時間性を評洒するために、RTK測 位における遅延時間を測定した。図 8 に実際に測 定した時間を模式的に示す。遅延時間は、受信機よ り出力されている1PPS信号の出力時刻から、利用者 局受信機において、RTKの測位データを出力し始め るまでに要した時間を、約 $15 \mathrm{kHz} の \mathrm{~A} / \mathrm{D}$ 変換器内部 クロックを用いて測定した。測位データには測位時 刻を示すGPS時間が含まれているので、1PPS信号が 出力されてから、測位データが出力されるまでの時 間を測定すれば、遅延時間を求めることができる。

図 9 に、この遅延時間の測位毎の変化を示す。平 均値は135.90ms、標準偏差は19.61msである。遅延時間がかなり長いものもあるが、これは利用者局受信 機より、パソコンに向けて、RTK測位データだけではなく、パソコンを制御するためのデータも出力され ているためであり、この制御データが出力されている時間帯では、遅延時間が長くなっている。また、こ の遅延時間は、測位計算に利用している衛星の数によっても変化し、同図より、利用衛星数が 6 機のとき よりも 7 機のときの方が、遅延時間が長くなっていることが分かる。衛星数にもよるが、この $135.90 \mathrm{~ms}$ 苂、 今回使用した受信機における、RTKの実時間性の限界であると考えられる。

\section{5.まとめ}

RTKを傾斜計として利用する場合に必要なスペックを、具体化するための基礎的データを収集するため に、利用者局受信機のアンテナを、シーソー運動する動摇台上の一端に設置し、RTK測位することによっ て、動的なRTK測位精度を評価する実験を行った。この結果は、動摇台の支点ーアンテナ間距離が $45 \mathrm{~cm}$ と短 いため、RTK測高度から求めた計算角度の誤差 $E a$ は、較正に用いた傾斜計の出力角度に対して $2.5^{\circ}$ 程度と なった。しかしながら、船舶上で使用する等のように、動摇台の支点一アンテナ間に相当する距離を長く とれるような場合には、このままの測高精度でも、十分に高精度な傾斜計を構成できることが分かった。

次に、RTKの実時間性を評価するために、利用者局受信機で、RTK測位データを出力し始めるまでに要 する時間を測定した。この結果、平均 $135.90 \mathrm{~ms} 、$ 標準偏差19.61ms要することが分かった。よって、この 135.90msが、今回使用した受信機によるRTKの実時間性の限界であると考えられる。

現在、ASHTECH社より市販されているRTK傾斜計3DF ADUでは、計算角度、実時間性に不明瞭な点 があり、実際の利用に際しては、それらを具体化する必要があると考えられる。

本研究の実験では、これらの不明瞭なスペックを明確化するための、基礎的データを収集したといえる。 また、搬送波位相積算值データや、RTK測位データにフィルタ処理等を行い、スムージングすれば、RTK 
を用いて、さらに高精度な傾斜計を構成することも可能であると考える。

今後、2 台のGPSアンテナをアームの両端に設置して、それぞれの受信機から出力された搬送波位相積 算值データから、直接傾斜角を算出するもので、さらに信頼性が高く、高性能なRTK傾斜計を構成する実 験を行いたいと考兄ている。

最後になりましたが、実験に協力して頂きました、鳥羽商船高等専門学校教官の鈴木治氏にお礼申し上 げます。

\section{参 考 文 献}

（1）王 盾・森川博之・水町守志：「キネマティックGPSにおけるサイクルスリップの逐次決定法」, 信学 技報，SANE93-84(1994-01)，pp.85～92，1994年1月。

（2）王 盾・森川博之・水町守志：「余剰GPS信号を利用するサイクルスリップの高精度決定法」，信学技 報，SANE93-105(1994-03)，pp.33〜40，1994年3月。

（3）王盾・森川博之・水町守志：「キネマティックGPSにおけるアンビギュイテイ高速解明法一整数制約 条件に基づくアプローチー」，電子情報通信学会論文誌B-II Vol.J78-B-II No.5，pp.306３16，1995 年5月。

（4）日本測地学会，「GPS一人工衛星による精密測位システムー」，社団法人 日本測量協会，1986年11月 10 日.

（5）土屋 淳・过 宏道：「やさしいGPS測量」, 社団法人 日本測量協会, 1991年10月5日

(6) 織田博行・五十嵐和之・関 信次・石井 真：「GPSを用いた運動測定システム」, 日本航海学会誌126号, 平成7年12月.

\section{質 疑 応 答}

塩見格一(電子航法研究所)：動摇台の支点ーアンテナ間距離を長くとれば、測角精度が向上すると考えて おられますか、実際の航空機や船舶では、支点一アンテナとして想定される部分か、その重量等により 歪み、RTKの測角誤差より大きな誤差を生じるのではないでしょうか。傾斜角度が大きい場合の、航空 機、船舶等のボディがぼの程度歪むのか、調査あるいは見当は付けられていますか。

浪江宏宗：実際に船舶にRTKを設置し、航行しながら測角する実験を行いましたか、当日はほとんぼ摇れ がなく、これについての検討ができる程度の結果が得られませんでした。今後の検討課題とさせて頂き ます。

奥田成幸 (運輸省海技大学校)：今回構成されましたRTK傾斜計は、アームの両端にアンテナを設置したも のと、同原理の傾斜計であると思われますが、キネマティックGPSを傾斜計に利用されなのはなぜです か。

安田明生：既に同様の傾斜計が市販されていることは承知しております。本文でも示しましたように、市 販されております製品の、性能等の記述は必ずしも十分ではなく、適用範囲も明確ではないようです。 同製品を正しく使いこな寸上でも、RTKの特性を十分に明確化する必要があり、また、今後の研究によ っては、さらに高性能、高信頼性の傾斜計を構成できる可能性もあると考えます。今回はそのための基 礎的データの取得に留まりましたが、今後は、アームの両端にアンテナを設置したRTK傾斜計を構成し、 研究を続けたいと考えております。

奥田成幸：RTKの実時間性の評価に、測位データの出力時刻を使用されているようですが、単にデータの 出力タイミングであって、リアルタイム性（データの同時刻性）を証明している訳ではないのではあり ませんか。

浪江宏宗：受信機より出力されている1PPS信号は、正確にGPS時間と同期しており、毎秒の正秒に出力さ れています。また、RTK測位データには、測位時刻（測位データの出力時刻ではない）が正秒のGPS時 間で含まれています。この測位データは、本来1PPS信号と同時に出力されなければ、真に実時間とはい えません。よって、1PPS信号出力時刻から、この時刻に出力される心゙き、RTK測位データの実際の出力 時刻までの時間を測定することで、RTKの害時間性が評価できると考えます。 